\title{
EXPERIENTIAL LEARNING METHODS IMPROVES RATIONAL PRESCRIBING SKILL IN MEDICAL STUDENTS
}

\author{
Mega Pandu Arfiyanti ${ }^{1 *}$, Gandes Retno Rahayu², Eti Nurwening Sholikhah ${ }^{3}$ \\ ${ }^{1}$ Medical Education and Development Unit, Faculty of Medicine, University of Muhammadiyah Semarang, Semarang- \\ INDONESIA \\ 2Department of Medical Education and Bioethics, Faculty of Medicine, Public Health and Nursing, Universitas Gadjah Mada, \\ Yogyakarta - INDONESIA \\ ${ }^{3}$ Department of Pharmacology and Therapy, Faculty of Medicine, Public Health and Nursing, Universitas Gadjah Mada, \\ Yogyakarta - INDONESIA
}

Submitted: 15 Jun 2020; Final Revision from Authors: 27 Apr 2021; Accepted: 09 May 2021

\begin{abstract}
Background: Rational prescribing is an important skill for medical doctors. Many graduates still feel insufficiently prepared to make rational prescribing and fail to demonstrate the related clinical reasoning after graduation. For these reasons, it is important to improve the medical student teaching of rational prescribing. The aim of this study is proving the effectiveness of experiential learning methods to improve rational prescribing skills of medical students.

Methods: This study used a one-group pretest-posttest design. Rational prescribing courses use experiential learning methods for 6 years medical students. Every student provided evaluation of rational prescribing and clinical reasoning through pretest and posttest, and we analyzed the results by paired t test.

Results: The change in the rational prescribing skill of the students is significant between pretest and posttest. However, in the hypertension case the scores are not significant between pretest and posttest. Also, the scores of clinical reasoning based on drug interaction and evidence-based methods are not significant in the hypertension and otitis media cases.

Conclusions: Experiential learning methods can enhance rational prescribing skill in medical students but the students were still not able to choose appropriate medications based on drug interaction and evidence-based approach.
\end{abstract}

Keywords: experiential learning, rational prescribing, pharmacotherapy, medical education

\section{ABSTRAK}

Latar belakang: Penulisan resep yang rasional adalah keterampilan yang penting bagi dokter. Banyak lulusan kedokteran yang masih merasa kurang siap dalam membuat resep yang rasional dan gagal menunjukkan alasan klinis pemilihan obat dalam resep. Untuk alasan ini, penting untuk meningkatkan pengajaran mahasiswa kedokteran tentang pembuatan resep yang rasional. Tujuan dari penelitian ini adalah membuktikan efektivitas metode experiential learning untuk meningkatkan keterampilan resep yang rasional dari mahasiswa kedokteran.

Metode: Penelitian ini menggunakan desain pretest one group pretest posttest. Praktek keterampilan pembuatan resep rasional menggunakan metode experiential learning dengan sampel mahasiswa kedokteran 6 tahun. Setiap siswa dievaluasi pembuatan resep rasionalnya dan penalaran klinis melalui pretest dan posttest, kemudian data di analisis menggunakan analisis data paired t-test.

*corresponding author, contact: megaarfiyanti@unimus.ac.id 
Hasil: Terdapat perubahan signifikan antara pretest dan posttest mahasiswa dalam keterampilan membuat resep rasional. Namun, dalam kasus hipertensi skornya tidak signifikan antara pretest dan posttest. Skor penalaran klinis berdasarkan interaksi obat dan metode berbasis bukti tidak signifikan untuk kasus hipertensi dan otitis media.

Kesimpulan: Metode experiential learning dapat meningkatkan keterampilan pembuatan resep rasional pada mahasiswa kedokteran, tetapi mahasiswa masih belum dapat memilih obat yang tepat berdasarkan interaksi obat dan pendekatan berbasis bukti.

Kata kunci: experiential learning; penulisan resep rasional; farmakoterapi; pendidikan kedokteran

\section{PRACTICE POINTS}

- Implementation of experiential learning method is greatly influenced by students' active engagement, the role of facilitators in providing direction and feedback, initial knowledge of the students and a conducive environment.

- Experiential learning is more suitable to be done in small groups.

\section{INTRODUCTION}

Rational prescribing is an essential skill for medical doctors. ${ }^{1}$ It can be found in pharmacotherapy lessons, but teaching pharmacotherapy is still not optimally implemented in many medical faculties even though the time allocated for the learning has been improved. ${ }^{2}$ Many graduates feel underprepared to demonstrate rational prescribing and clinical reasoning after graduation. They often do not understand the basic principles of rational prescribing which include the suitability of dosage, duration of use, drug interaction and suitability of diagnostic reasoning. ${ }^{1-3}$ Based on an online survey of medical graduates in the UK in 2008, many graduates still feel insufficiently prepared to assume prescription responsibilities after graduation. ${ }^{4-6}$

Pharmacotherapy learning in the medical faculty of many universities is often not optimal, and the level competence of therapy is lower than other competences (i.e., anamnesis, physical examination, and diagnostic procedure). One reason is the method of learning such as conventional lectures which cause students to be passive in the learning process. Learning methods can be replaced using experiential learning methods which can stimulate students more actively in learning aimed at improving skills in pharmacotherapy learning, such as prescribing and applying evidence-based methods. In some universities, the experiential learning theory created by Kolb is used as an alternative method of pharmacotherapy learning to increase students' active engagement. Experiential learning theory consists of four interconnected phases, which are: to do or feel, observe, contemplate or think, and plan/ execute. $^{\text {? }}$

Experiential learning methods in most faculties of medicine is identical with clinical education, whereas actual experiential learning can be done in undergraduate medical education in the form of lab work in the anatomical laboratory by using cadavers, simulation with patients, role play with friends, or practicing clinical skills using mannequins. ${ }^{8}$ Several previous studies have suggested that experiential learning methods are effective in improving prescribing skill and pharmacotherapy learning. ${ }^{9-11}$ In this study, we describe all of the steps of the experiential learning method, using three cases in accordance with the competence standards of medical doctors in Indonesia and the skill of prescribing is assessed based on scores of a pretest and posttest.

The WHO 6 step rational prescribing method is the only validated guideline of pharmacology and 
pharmacotherapy which can be given to students by experiential learning methods. ${ }^{12}$ Two previous studies have examined the long-term effects of using the WHO 6 step method for rational prescribing in medical education curriculum and reported improvements in the rational prescribing skill. ${ }^{12,13}$ The WHO 6-step method has been delivered through interactive lectures, small group tutorials and clinical skills practice. Therefore, the use of experiential learning methods should be seriously considered because the experiential learning method is an active learning method that has not been widely used to teach the learning of the skill of rational prescribing in medical students. The aim of this study is proving the effectiveness of experiential learning methods to improve rational prescribing skills of medical students.

\section{METHODS}

\section{Study design, setting and population}

This study used quasi experimental design with one group pretest-posttest design. The population used in this study were 40 medical students who had completed the clinical rotation. The sample was selected using a total sampling method with inclusion criteria having completed clinical rotation and had signed an informed consent with a total sample of 40 persons. The sample was randomly divided into 4 small groups with a total of 10 participants in each small group to facilitate discussion using the experiential learning method. This research was conducted in February 2017 at Faculty of Medicine Universitas Muhammadiyah Semarang Indonesia. Participants were trained in rational prescribing skills using experiential learning methods and then we assessed the prescribing skill and the level of clinical reasoning by comparing pretest and posttest scores. Each prescription was assessed by two assessors, and a pharmacology lecturer from another institution who does not know the student. The cases involved patients with Diabetes Mellitus, hypertension and acute otitis media. These cases were chosen according to the competence level of general practitioners listed in Indonesian Doctor Competency Standards.

\section{Study questionnaire}

The instrument used in this study to assess the prescribing and clinical reasoning skills was the rubric for Prescription Quality Index ${ }^{14}$, which has been validated and the legibility test was done by the lecturer of pharmacology. The Prescription Quality Index has been shown to be a valid, reliable and responsive tool to measure quality of prescription.

\section{Data collection methods and ethical approval}

The procedures of this study are schematized in Figure 1 . The first day was concrete experience stage, in large group, 3 participants make simulation with 3 cases. Each participant observes and makes a rational prescribing and clinical reasoning assessed as pretest. The second to fourth days are the stages of reflective observation and abstract conceptualization. At this stage the participants discuss in small groups (10 people) with 1 lecturer as a facilitator. Each participant reflects on the experience of making rational prescription and application of clinical reasoning and then the lecturer giving structured feedback. At this stage, participants can reflect at least once according to the activity of each participant. After finishing the discussion in small groups, it was continued to debriefing session with an expert in internal medicine and ENT. After that, each group discussed a therapy plan based on reflection and expert answers in debriefing session. On the last day for active experimentation, each participant made a prescription from 3 different case simulations but with the same theme and were assessed as the posttest. This study was conducted for 5 days, with the consent of the participating students after we received permission from Medical and Health Research Ethics Committee, Faculty of Medicine Universitas Gadjah Mada.

\section{Data analysis}

Normality test data was analyzed by using the Shapiro Wilk test, then the values of pretest and posttest in the analysis were compared by using paired $t$ test. The paired $t$ test was used to determine the mean difference between the pretest and posttest scores of the paired gro 


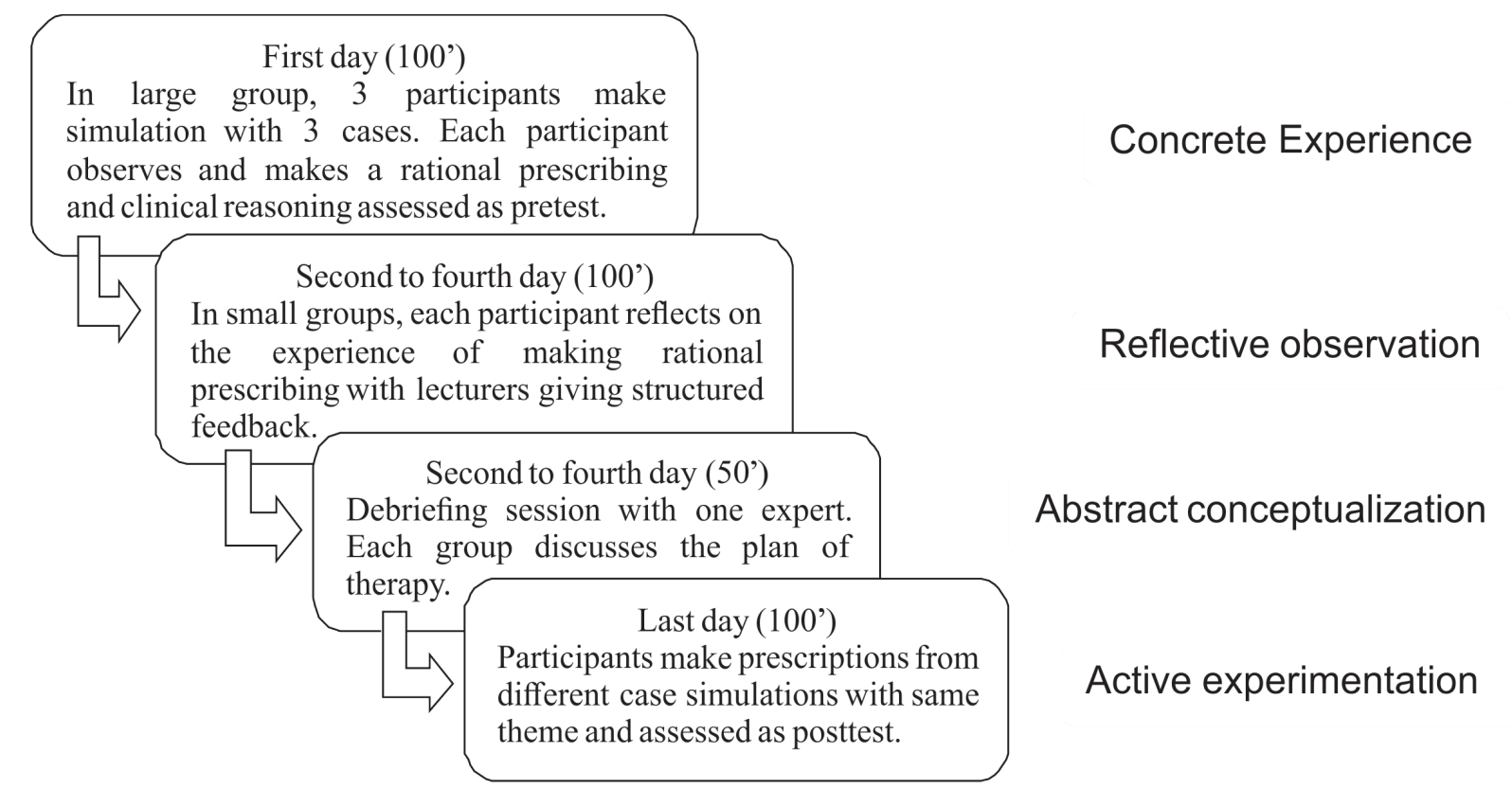

Figure 1. Study procedure

\section{RESULTS AND DISCUSSION}

The results of this study demonstrate that using experiential learning methods can improve rational prescribing skills of participants. In the concrete experience cycle in this study, participants were invited to do simulation of rational prescribing through the WHO 6 step guiding method. The simulation method was chosen because this method is more effective to be used to teach skills both in undergraduate and clinical education. ${ }^{15-17}$ Students who follow this research have passed the clinical education stage but they are still not confident to choose appropriate therapy based on evidence based methods. Students need to have real experience for making rational prescribing since undergraduate level education is conducted more through simulation scenarios or roleplays building on the basic pharmacology lessons. ${ }^{10,18}$

The result of pretest and posttest scores before being analyzed using paired $t$ test was done by Shapiro Wilk data normality test with pretest sig value 0.290 and value of posttest sig value 0.319 , which meant data of pretest and posttest values had normal distribution. The results of paired $t$ test based on each case is listed in Table 1. The difference of the pretest and posttest scores showed significant differences in the Diabetes Mellitus and Acute Otitis Media case, but the results in the hypertension case did not show significant difference with value $\mathrm{p}=0.821$.

Table 1. Mean of pretest and posttest for each case

\begin{tabular}{|ccccccccc}
\multirow{2}{*}{ Case } & & \multicolumn{2}{c}{ Pretest } & \multicolumn{2}{c}{ Posttest } & Delta & $\begin{array}{c}\text { Sig. } \\
\text { mean }\end{array}$ \\
\cline { 3 - 7 } & & Mean & SD & Mean & SD & & tailed) \\
Hypertension & 40 & 61.93 & 9.80 & 61.48 & 7.17 & -0.45 & 0.821 \\
Diabetes Mellitus & 40 & 60.55 & 7.83 & 67.69 & 7.54 & 7.14 & 0.000 \\
Acute Otitis Media & 40 & 59.25 & 8.10 & 63.63 & 7.25 & 4.38 & 0.003 \\
\hline \multicolumn{1}{c}{ Total } & 40 & 60.58 & 5.79 & 64.20 & 5.09 & 3.62 & 0.001 \\
\hline
\end{tabular}

$\operatorname{ig}(2$-tailed $)<0.05$ is significant 
On the first day of reflective observation, for the hypertension case, participants were still hesitant to do self-reflection, and only a few students dared to reflect. On the second and third days of reflection for the cases of Diabetes Mellitus and acute otitis media, students made a better reflection, explaining what is lacking at the time of prescribing and were daring to plan their improvement. At this stage the facilitator guided the reflection process and provided structured feedback. The participant's skill of prescribing based on how many reflections were done statistically had a more significant score for students who did reflections more than 1 time (Table 2).

Table 2. Mean pretest and posttest based on reflection

\begin{tabular}{|c|c|c|c|c|c|c|c|}
\hline \multirow{2}{*}{ Reflection } & \multirow{2}{*}{$\mathbf{N}$} & \multicolumn{2}{|c|}{ Pretest } & \multicolumn{2}{|c|}{ posttest } & \multirow{2}{*}{$\begin{array}{l}\text { Delta } \\
\text { mean }\end{array}$} & \multirow{2}{*}{$\begin{array}{c}\text { Sig. } \\
\text { (2-tailed) }\end{array}$} \\
\hline & & Mean & SD & Mean & SD & & \\
\hline 1 reflection & 15 & 65.39 & 3.33 & 63.24 & 4.16 & 2.15 & 0.025 \\
\hline$>1$ reflection & 25 & 57.59 & 4.99 & 64.77 & 5.57 & -7.08 & 0.000 \\
\hline
\end{tabular}

ig (2tailed) $<0.05$ is significant

In this study, students who made more than one reflection had a statistically significant difference in pretest and posttest values. By doing reflections, the students realized the advantages and disadvantages themselves. ${ }^{19}$ Research shows that self-reflection accompanied by the provision of structured feedback will improve the achievement, help the development of understanding and student's skills and can motivate students by spurring them to recognize their efforts in the learning process. ${ }^{20}$ The reflection process is influenced by students' understanding of the overall purpose of the reflection process they perform, the motivation for reflection, the absence of feedback and the lack of time for reflection. ${ }^{21}$
The abstract conceptualization cycle in this research presented an expert of science of Internal Medicine and ENT to answer questions from participants about aspects which were still unclear when students did reflective observation. This stage becomes important because the students will have a rationality based on the conclusions of the experience they have done and the theory they have learned. ${ }^{22}$ In the active experimentation cycle in this study, students made rational prescribing based on different case simulations about diabetes mellitus, hypertension and acute otitis media.

In this study we also compared the average difference and $p$-value based on cases and constructs after the analysis with paired $t$ test. Results are listed in Table 3 .

Table 3. Delta mean posttest-pretest and p value based on case and construct

\begin{tabular}{lccccccc}
\multirow{2}{*}{ Construct } & $\mathbf{N}$ & \multicolumn{2}{c}{ Hypertension } & \multicolumn{2}{c}{ Diabetes mellitus } & \multicolumn{2}{c}{ Acute otitis media } \\
\cline { 3 - 8 } & & Delta mean & $\mathbf{p}$ & Delta mean & $\mathbf{p}$ & Delta mean & $\mathbf{p}$ \\
Evidence based & 40 & 1.85 & 0.083 & 7.62 & 0.000 & 1.02 & 0.414 \\
Drug interaction & 40 & -0.70 & 0.678 & 5.08 & 0.000 & -1.87 & 0.028 \\
Drug rationality & 40 & 1.40 & 0.036 & 3.69 & 0.000 & 5.15 & 0.000 \\
Completeness recipe & 40 & 3.35 & 0.002 & 3.89 & 0.000 & 2.95 & 0.000 \\
structure & & & & & & & \\
\hline
\end{tabular}

${ }^{*} \mathrm{p}<0.05$ is significant 
Based on the data in Table 3, students are still unable to make an appropriate prescribing, especially regarding the appropriate selection of drugs based on an evidence-based. The ability of students to make a rational prescribing increased significantly, but students still were not able to choose the appropriate medicine based on evidence-based, especially in cases of hypertension. The large number of antihypertensive drugs, potential risks for side-effects, drug interactions, and decreased adherence to treatment are factors which make it difficult for students to determine hypertension therapy. ${ }^{23}$ In line with the results of this study, students felt able to write prescriptions but they are not yet confident enough to choose the appropriate medication. ${ }^{10}$ Students' motivation to reflect, prior knowledge and students' ability to know what to remember can also be contributing factors. ${ }^{24}$

The application of experiential learning methods at the undergraduate stage can be done on a single block of pharmacology, with theoretical delivery through large class lectures and prescribing skills in small groups. Students can learn to make prescriptions through simulations of various cases to provide a real-life experience. Experiential learning given to undergraduate students will make it easier for students to adapt while taking clinical rotation, increasing student motivation, and improving students' self-confidence when dealing with patients, while strengthening and deepening cognitive, contextual knowledge, and ability in integrating difficult concepts with appropriate medical education. ${ }^{25}$

However, the successful implementation of experiential learning method is greatly influenced by students' active engagement, the role of facilitators in providing direction and feedback, initial knowledge of the students and a conducive environment. Generally, experiential learning is more suitable to be done in small groups. Implementation in a large class will have considerable constraints in the process of reflective observation and abstract conceptualization. The weakness of this study was conducted with a small number of samples, the research time was short and used a quasi-experimental method. Moreover, the success of this method depends on the activeness of the participants.

\section{CONCLUSION}

The use of experiential learning methods can improve rational prescribing skill of medical students, but they still were not able to choose appropriate medications based on evidence based, especially in cases of hypertension. Students who made more than one reflection had a more significant difference in pretest and posttest values.

\section{RECOMMENDATION}

It is necessary to conduct a similar study using experimental methods with a control group, with a longer study period, and using more varied cases. Implementation of experiential learning methods is greatly influenced by students' active engagement, the role of the facilitators in providing direction and feedback, initial knowledge of students and a conducive environment for experiential and reflective learning. Implementation of experiential learning methods to teach rational prescribing skill can be done from the undergraduate stage through case simulation and small group reflection with expert feedback to increase student confidence when entering clinic rotation.

\section{COMPETING INTERESTS}

This study was based on the author's master thesis titled: The use of experiential learning method to improve the skill of making a rational prescribing. Nevertheless, it has not been submitted or under review in any other journals.

\section{AUTHORS' CONTRIBUTION}

Mega Pandu Arfiyanti - concept and design of the study, data collection, analysis and interpretation, and the first draft of the paper and further manuscript

Gandes Retno Rahayu - concept and design of the study, the data analysis and interpretation, contributing to the writing of the paper 
Eti Nurwening Sholikhah - concept and design of the study, the data collection and analysis, contributing to the writing of the paper

\section{REFERENCES}

1. Richir MC, Tichelaar J, Stam F, Thijs A, Danner SA, Schneider AJ, et al. A context-learning pharmacotherapy program for preclinical medical students leads to more rational drug prescribing during their clinical clerkship in internal medicine. Clin Pharmacol Ther. 2008;84(4):513-6.

2. Han WH, Maxwell SRJ. Are medical students adequately trained to prescribe at the point of sgraduation? Views of first year foundation doctors. Scott Med J. 2006;51(4):27-32.

3. Aronson JK. Editors' view: A prescription for better prescribing. Br J Clin Pharmacol. 2006;61(5):487-91.

4. Van Unen RJ, Tichelaar J, Schneider AJ, Geijteman ECT, Nanayakkara PWB, Thijs A, et al. The feasibility of incorporating structured therapeutic consultations with real patients into the clinical clerkship internal medicine. Naunyn Schmiedebergs Arch Pharmacol. 2012;385(11):1111-6.

5. Heaton A, Webb DJ, Maxwell SRJ. Undergraduate preparation for prescribing: The views of 2413 UK medical students and recent graduates. Br J Clin Pharmacol. 2008;66(1):128-34.

6. Hay A, Smithson S, Mann K, Dornan T. Medical students' reactions to an experience-based learning model of clinical education. Perspect Med Educ. 2013;2(2):58-71.

7. Kolb D. Experiential learning: Experience as the source of learning and development. FT Press. 2014. 31-40 p.

8. Yardley S, Teunissen PW, Dornan T. Experiential learning: AMEE Guide No. 63. Med Teach. 2012;34(2).

9. Akici A, Gören MZ, Aypak C, Terzioglu B, Oktay S. Prescription audit adjunct to rational pharmacotherapy education improves prescribing skills of medical students. Eur J Clin Pharmacol. 2005;61(9):643-50.

10. Brinkman DJ, Tichelaar J, Van Agtmael MA, De Vries TPGM, Richir MC. Self-reported confidence in prescribing skills correlates poorly with assessed competence in fourth-year medical students. J Clin Pharmacol. 2015;55(7):825-30.

11. Makmor-Bakry M, Azmi N, Ali AM. Mannequin-simulator as a new teaching and learning method in performance-based pharmacotherapy. Indian J Pharm Educ Res. 2013;47(3):1-5.

12. Richir MC, Tichelaar J, Geijteman ECT, De Vries TPGM. Teaching clinical pharmacology and therapeutics with an emphasis on the therapeutic reasoning of undergraduate medical students. Eur J Clin Pharmacol. 2008;64(2):217-24.

13. Hogerzeil H V, Barnes KI, Henning RH, Kocabasoglu YE, Moller H, Smith AJ, et al. World Health Organization Essential Drugs and Medicines Policy Geneva. 2001;

14. Hassan NB, Ismail HC, Naing L, Conroy RM, Abdul Rahman AR. Development and validation of a new Prescription Quality Index. Br J Clin Pharmacol. 2010;70(4):500-13.

15. Issenberg SB, McGaghie WC, Petrusa ER, Gordon DL, Scalese RJ. Features and uses of high-fidelity medical simulations that lead to effective learning: A BEME systematic review. Med Teach. 2005;27(1):10-28.

16. McGaghie WC. Does simulation based medical education with deliberate practice yield better results than traditional clinical education? a meta analytic comparative review of the evidence. Acadm Meded. 2012;86(6):706-11.

17. Steadman RH, Coates WC, Yue MH, Matevosian R, Larmon BR, McCullough L, et al. Simulation-based training is superior to problem-based learning for the acquisition of critical assessment and management skills. Crit Care Med. 2006;34(1):151-7.

18. Illing J, Morrow G, Kergon C, Burford B, Spencer J, Peile E, et al. How prepared are medical 
graduates to begin practice? A comparison of three diverse UK medical schools. Rep to Educ Comm [Internet]. 2008;(September). Available from: http://wrap.warwick.ac.uk/48953/

19. Muir F. The understanding and experience of students, tutors and educators regarding reflection in medical education: a qualitative study. Int J Med Educ. 2010;1:61-7.

20. Rowe AD, Wood LN. Student perceptions and preferences for feedback. Asian Soc Sci. 2008;3:78-88.

21. Sandars J. The use of reflection in medical education: AMEE Guide No. 44. Med Teach. 2009;31(8):685-95.
22. Fanning RM, Gaba DM. The role of debriefing in simulation-based learning. Simul Healthc. 2007;2(2):115-25.

23. Cooney D, Pascuzzi K. Polypharmacy in the Elderly: Focus on Drug Interactions and Adherence in Hypertension. Clin Geriatr Med [Internet]. 2009;25(2):221-33. Available from: http://dx.doi.org/10.1016/j.cger.2009.01.005

24. Kolb AY, Kolb DA. Learning Styes and Learning Spaces: A review of Multidisciplnary Application of Experiental Learning Theory in Higher Education. 2004;(January).

25. Dornan T, Bundy C. What can experience add to early medical education? Consensus survey. Bmj. 2004;329(7470):834. 